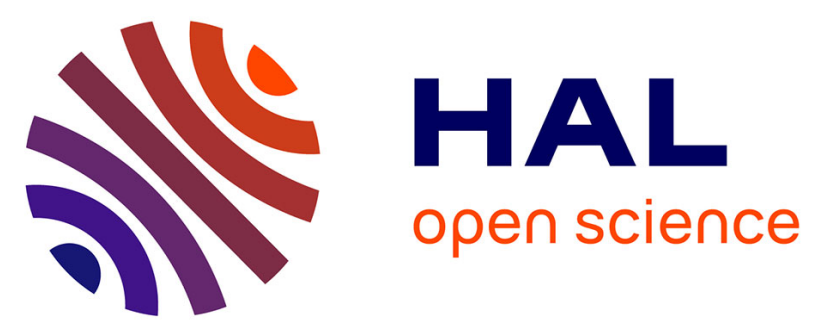

\title{
Effect of phosphorus on tricalcium silicate T1: from synthesis to structural characterization
}

Marie-Noëlle de Noirfontaine, Sandrine Tusseau-Nenez, Marcel Signes-Frehel, Gilles Gasecki, Caroline Girod-Labianca

\section{- To cite this version:}

Marie-Noëlle de Noirfontaine, Sandrine Tusseau-Nenez, Marcel Signes-Frehel, Gilles Gasecki, Caroline Girod-Labianca. Effect of phosphorus on tricalcium silicate T1: from synthesis to structural characterization. Journal of the American Ceramic Society, 2009, 92 (10), pp.2337-2344. 10.1111/j.15512916.2009.03092.x . hal-00421577

\section{HAL Id: hal-00421577 \\ https://hal.science/hal-00421577}

Submitted on 14 Dec 2010

HAL is a multi-disciplinary open access archive for the deposit and dissemination of scientific research documents, whether they are published or not. The documents may come from teaching and research institutions in France or abroad, or from public or private research centers.
L'archive ouverte pluridisciplinaire HAL, est destinée au dépôt et à la diffusion de documents scientifiques de niveau recherche, publiés ou non, émanant des établissements d'enseignement et de recherche français ou étrangers, des laboratoires publics ou privés. 


\title{
Effect of phosphorus impurity on tricalcium silicate T1: from synthesis to structural characterization
}

\author{
Marie-Noëlle de Noirfontaine, ${ }^{\dagger, 1}$ Sandrine Tusseau-Nenez, ${ }^{\star, 1}$ Marcel Signes-Frehel, ${ }^{2}$ Gilles \\ Gasecki, $^{2}$ and Caroline Girod-Labianca ${ }^{1,2}$
}

${ }^{1}$ CECM, CNRS UPR 2801, F-94407 Vitry-sur-Seine, France

${ }^{2}$ CTG-Italcementi Group, BP01, F-78931 Guerville, France

\begin{abstract}
Alite is the major compound of anhydrous Portland cement: it is composed of tricalcium silicate $\mathrm{Ca}_{3} \mathrm{SiO}_{5}\left(\mathrm{C}_{3} \mathrm{~S}\right)$ modified in composition and crystal structure by ionic substitutions. Alite is also the main hydraulic phase of cement and the most important for subsequent strength development. Using raw meals (rich in $\mathrm{Ca}_{3} \mathrm{P}_{2} \mathrm{O}_{8}$ ) as alternative fuels in cement plants raises the question about the effect of phosphorus on $\mathrm{C}_{3} \mathrm{~S}$ and its consequences on reactivity with water. This paper deals with a systematic study of $\mathrm{C}_{3} \mathrm{~S}$ triclinic $\mathrm{T}_{1}$ polymorph doped with $\mathrm{P}_{2} \mathrm{O}_{5}$ in the range 0 to 0.9 wt. \%. All the samples were characterized by X-ray powder diffraction (XRD), scanning electron microscopy (SEM) and electron-microprobe analysis (EMPA). The appearance of a phase rich in phosphorus is shown. It displays a structure derivative of the $\alpha^{\prime}{ }_{\mathrm{H}}-\mathrm{Ca}_{2} \mathrm{SiO}_{4}$ polymorph, noted $\alpha^{\prime}{ }_{\mathrm{H}}-\mathrm{C}_{2} \mathrm{~S}(\mathrm{P})$. As phosphorus content increases, $\mathrm{C}_{3} \mathrm{~S}$ is more and more decomposed into free lime and $\alpha^{\prime}{ }_{\mathrm{H}}-\mathrm{C}_{2} \mathrm{~S}(\mathrm{P})$. The $\alpha^{\prime}{ }_{\mathrm{H}}$ phase was detected from 0.1 wt. $\% \mathrm{P}_{2} \mathrm{O}_{5}$ and located at the interfaces of $\mathrm{C}_{3} \mathrm{~S}$ grains. Two identification keys are proposed in order to highlight the $\alpha^{\prime}{ }_{\mathrm{H}}-\mathrm{C}_{2} \mathrm{~S}(\mathrm{P})$ phase: the XRD angular window at $2 \theta_{\mathrm{Cu}}=32.8-33.2^{\circ}$ and a smooth aspect on SEM micrographs.
\end{abstract}

This work was financially supported by CTG-Italcementi Group.

${ }^{\dagger}$ Author to whom correspondence should be addressed. e-mail: marie-noelle.de-noirfontaine@polytechnique.edu Current address: LSI, CNRS UMR 7642, Ecole Polytechnique, 91128 Palaiseau, France

* Current address: ICMPE, CNRS UMR 7182 -Université Paris 12, 2-8 rue Henri Dunant, 94320 Thiais, France 


\section{Introduction}

Cement is one of the most ancient building materials. Today it remains the most commonly used, with an annual production of about 2 billions tons in the world. Surprisingly, cement still requires basic researches to develop accurate characterization methods in order to understand its chemical and physical properties. Anhydrous Portland cement is a mixture of clinker and gypsum, the latter being used to delay the setting. The clinker is a heterogeneous material, composed of at least four phases. The two major phases are calcium silicates: tricalcium silicate $\mathrm{Ca}_{3} \mathrm{SiO}_{5}$ (referred to as $\mathrm{C}_{3} \mathrm{~S}$ ) and dicalcium silicate $\mathrm{Ca}_{2} \mathrm{SiO}_{4}$ (referred to as $\mathrm{C}_{2} \mathrm{~S}$ ). The two other phases are calcium aluminates $\mathrm{Ca}_{3} \mathrm{Al}_{2} \mathrm{O}_{6}\left(\mathrm{C}_{3} \mathrm{~A}\right)$ and $\mathrm{Ca}_{4} \mathrm{Al}_{2} \mathrm{Fe}_{2} \mathrm{O}_{10}\left(\mathrm{C}_{4} \mathrm{AF}\right)^{\S}$. In fact, most of the calcium silicate phases are not pure: they are observed as solid solutions, called alite and belite for the $\mathrm{C}_{3} \mathrm{~S}$ and $\mathrm{C}_{2} \mathrm{~S}$ basedphases respectively. Both calcium silicates generate the hydrates responsible for the mechanical properties of the hydrated cement. $\mathrm{C}_{3} \mathrm{~S}$ reacts faster than $\mathrm{C}_{2} \mathrm{~S}$ with water, and then predominantly participates in the short term strength.

The polymorphs actually observed depend on the nature and the concentration of impurities (also called minors) in the solid solutions ${ }^{1}$. These impurities, added either deliberately or accidentally, are introduced either by the raw material or by the fuel used for calcination. Due to their effects on the calcium silicate polymorphs, one observes an alteration of both hydration reaction and the final hydrated cement properties in terms of setting and mechanical resistance. For all these reasons, it appears as important to correlate the minor elements found in clinker with the cement reactivity.

Ordinary Portland cement always contains phosphorus in the range 0.2 to 0.3 weight percent (wt. \%) $\mathrm{P}_{2} \mathrm{O}_{5}{ }^{1, * *}$. The effect of phosphorus was studied since 1950 until the 1980's in order to validate the use of phosphorus-rich limestone quarries, such as the phosphatic rocks of West Uganda $^{2-5}$. These authors investigated clinkers with phosphorus concentration above 1 wt. $\% \mathrm{P}_{2} \mathrm{O}_{5}$. The major effect of phosphorus addition is to decrease the alite/belite ratio, with a strong deterioration of the mechanical properties of the hydrated cement, since alite is the main hydraulic phase in clinker. For each additional of $\mathrm{P}_{2} \mathrm{O}_{5}$ above 1 wt. $\%$, the alite concentration decreases with

\footnotetext{
$\S$ using the abbreviated oxide notation: $\mathrm{C}=\mathrm{CaO}, \mathrm{S}=\mathrm{SiO}_{2}, \mathrm{~A}=\mathrm{Al}_{2} \mathrm{O}_{3}, \mathrm{~F}=\mathrm{Fe}_{2} \mathrm{O}_{3}, \mathrm{H}=\mathrm{H}_{2} \mathrm{O}, \mathrm{P}=\mathrm{P}_{2} \mathrm{O}_{5}$

${ }^{* *}$ Unlike the phosphatic cements, which exhibit high phosphorus content and distinct chemical species (as $\mathrm{C}_{3} \mathrm{P}$ ), ordinary Portland cements contain only a low phosphorus concentration.
} 
9.9 wt. $\%$ whereas the belite concentration increases with 10.9 wt. \%. Above 2.25 wt. $\% \mathrm{P}_{2} \mathrm{O}_{5}$, the clinker is no more acceptable for cement production ${ }^{2}$.

Few studies are related to the effect of phosphorus below 1 wt. $\% \mathrm{P}_{2} \mathrm{O}_{5}{ }^{3-5}$. Since 1998 , raw meals are used as alternative fuels in cement plants. The ashes of raw meals (rich in $\mathrm{Ca}_{3} \mathrm{P}_{2} \mathrm{O}_{8}$, referred to as $\mathrm{C}_{3} \mathrm{P}$ ) produced in the furnace during the clinker production are the origin of phosphorus incorporation into the phases of clinker. Therefore, the opened question of the effect of phosphorus in small quantities became subject for discussion. Above 0.5 wt. $\% \mathrm{P}_{2} \mathrm{O}_{5}$, Kwon et al. ${ }^{6}$ observe the decomposition of alite into belite and free lime. Phosphorus is located in the two calcium silicates, preferentially in belite ${ }^{7,8}$. However, some authors suggest a possible effect of very low contents of phosphorus on the tricalcium silicate reactivity ${ }^{3}$.

Some studies on synthetic silicates samples are dedicated to the structural modifications induced by impurities (Table I). Most of the studies deal with synthetic $\mathrm{C}_{2} \mathrm{~S}$ doped samples, with possible crossed effects of the various impurities added $\left(\mathrm{P}_{2} \mathrm{O}_{5}\right.$, coupled with $\mathrm{Fe}_{2} \mathrm{O}_{3}$ or $\left.\mathrm{Cr}_{2} \mathrm{O}_{3}\right)$. Whatever the nature of the various impurities added, phosphorus induces a structural transition from the monoclinic $\beta-C_{2} S$ polymorph to the orthorhombic $\alpha^{\prime}\left(\alpha^{\prime}{ }_{H}\right.$ and $\left.\alpha^{\prime}{ }_{L}\right)$ polymorphs, or to the hexagonal $\alpha$ polymorph in a minor way. Using X-ray diffraction on single crystal, Saalfeld and Klaska $^{9}$ investigated the structure of a $\mathrm{C}_{2} \mathrm{~S}$ sample doped with phosphorus $\left(6 \mathrm{C}_{2} \mathrm{~S} .1 \mathrm{C}_{3} \mathrm{P}\right)$ : they discovered a superstructure along $b$ axis of the $\alpha^{\prime}$ basic structure previously determined ${ }^{10,11}$. Using synchrotron X-ray powder diffraction, Mumme et al. ${ }^{12}$ studied the stabilized structures of $\mathrm{C}_{2} \mathrm{~S}$ doped with the only phosphorus impurity. They found two possible $\alpha^{\prime}{ }_{H}$ structures depending on the amount of phosphorus: the basic structure for $\mathrm{C}_{2} \mathrm{~S}+5 \%$ mol $\mathrm{C}_{3} \mathrm{P}$ and the superstructure of Saalfeld ${ }^{\dagger \dagger}$ for $\mathrm{C}_{2} \mathrm{~S}+10 \% \mathrm{~mol} \mathrm{C}_{3} \mathrm{P}\left(6 \mathrm{C}_{2} \mathrm{~S} \cdot 1 \mathrm{C}_{3} \mathrm{P}\right)$. Fukuda et al. ${ }^{13}$ studied by TEM the $\alpha-\alpha$ phase transitions in various belites as a function of $\mathrm{P} / \mathrm{Si}$ ratio. Concerning $\mathrm{C}_{3} \mathrm{~S}$, the literature exhibits only one study of alites with low phosphorus concentration ${ }^{14}$. Once again, $\mathrm{P}_{2} \mathrm{O}_{5}$ impurity is coupled with another impurity: $\mathrm{Mn}_{2} \mathrm{O}_{3}$. The authors observed $\mathrm{M} 3$ polymorph for alite. Above 1.56 wt. $\% \mathrm{P}_{2} \mathrm{O}_{5}$, alite is decomposed into $\mathrm{C}_{2} \mathrm{~S}$ and lime. When $\mathrm{P}_{2} \mathrm{O}_{5}$ content increases, the $\beta-\mathrm{C}_{2} \mathrm{~S}$ polymorph is converted into the $\alpha$ ' polymorph, as previously shown.

Unfortunately, both the nature and the concentration of other impurities (such as $\mathrm{Mn}_{2} \mathrm{O}_{3}$, $\mathrm{Fe}_{2} \mathrm{O}_{3}$ and $\mathrm{Cr}_{2} \mathrm{O}_{3}$ ) vary between the various studies, and no overall conclusion can be drawn

${ }^{\dagger \dagger}$ The superstructure of Saalfeld is referred to as " $\alpha-C_{2} S$ " in the paper of Mumme. 
concerning the solubility limit of phosphorus. To our knowledge, no systematic study is found in the literature devoted to the relation between the localization of phosphorus in $\mathrm{T}_{1} \mathrm{C}_{3} \mathrm{~S}$ polymorph and the properties of hydrated products for low phosphorus concentration. Therefore, in order to avoid possible crossed effect of impurities, and as a starting point for subsequent studies varying the impurities, we have chosen to investigate in this paper an alite with phosphorus as the only impurity.

This paper deals with a systematic structural study of tricalcium silicate T1 doped between 0 and 0.9 wt. $\% \mathrm{P}_{2} \mathrm{O}_{5}$ by $\mathrm{X}$-ray diffraction analysis (XRD), together with scanning electron microscopy (SEM coupled with EDS analysis) and Castaing electron micro-probe analysis (EMPA).

Table I. Phosphorus effects on the structure of alite (impure $\mathrm{C}_{3} S$ ) and belite (impure $\mathrm{C}_{2} \mathrm{~S}$ ): stabilized polymorphs versus chemical composition of the samples. Mumme et al. only reported the expected $\mathrm{P}_{2} \mathrm{O}_{5}$ content (no chemical analysis after synthesis is mentioned). The type of $\alpha^{\prime}$ polymorph is specified when sufficient crystallographic data is given by the authors

\begin{tabular}{|c|c|c|c|c|c|c|c|c|c|c|c|}
\hline \multirow[t]{2}{*}{ Sample } & \multicolumn{7}{|c|}{$\begin{array}{l}\text { Chemical composition } \\
\text { (wt. \%) }\end{array}$} & \multicolumn{3}{|c|}{$\begin{array}{c}\text { Stabilized } \\
\text { polymorph }^{\S}\end{array}$} & \multirow[t]{2}{*}{ References } \\
\hline & $\mathrm{CaO}$ & $\mathrm{SiO}_{2}$ & $\mathrm{P}_{2} \mathrm{O}_{5}$ & $\mathrm{Mn}_{2} \mathrm{O}_{3}$ & $\mathrm{Fe}_{2} \mathrm{O}_{3}$ & $\mathrm{Cr}_{2} \mathrm{O}_{3}$ & $\mathrm{Al}_{2} \mathrm{O}_{3}$ & $\mathrm{~K}_{2} \mathrm{O}$ & $\mathrm{C}_{2} \mathrm{~S}$ & $\mathrm{C}_{3} \mathrm{~S}$ & \\
\hline $\mathrm{C}_{2} \mathrm{~S}$ & 65.12 & 34.88 & 0 & 0 & 0 & 0 & 0 & 0 & $\beta>\gamma$ & & Benarchid et al. ${ }^{15}$ \\
\hline $\mathrm{C}_{2} \mathrm{~S}$ & 65.12 & 34.88 & 0 & 0 & 0 & 0 & 0 & 0 & $\gamma>\beta$ & & Qotaibi et al. ${ }^{16}$ \\
\hline Belite & 64.56 & 34.58 & 0.41 & 0 & 0 & 0.44 & 0 & 0 & $\beta>\gamma$ & & Qotaibi et al. ${ }^{16}$ \\
\hline Belite & 62.88 & 33.68 & 1.66 & 0 & 0 & 1.77 & 0 & 0 & $\beta$ & & Qotaibi et al. ${ }^{16}$ \\
\hline Belite & 62.25 & 33.34 & 2.07 & 0 & 2.33 & 0 & 0 & 0 & $\beta$ & & Benarchid et al. ${ }^{15}$ \\
\hline Belite & 62.32 & 33.38 & 2.08 & 0 & 0 & 2.22 & 0 & 0 & $\beta=\alpha$ & & Qotaibi et al. ${ }^{16}$ \\
\hline Belite & 63.27 & 32.19 & 3.54 & 0 & 0.68 & 0 & 0.11 & 0.12 & $\alpha_{L}^{\prime}$ & & Fukuda et al. $^{13}$ \\
\hline Belite & 59.48 & 31.86 & 4.18 & 0 & 0 & 4.48 & 0 & 0 & $\alpha^{\prime}>\beta$ & & Qotaibi et al. ${ }^{16}$ \\
\hline Belite & 59.34 & 31.79 & 4.17 & 0 & 4.69 & 0 & 0 & 0 & $\alpha^{\prime}$ & & Benarchid et al. ${ }^{15}$ \\
\hline Belite & 63.44 & 31.08 & 4.90 & 0 & 0.67 & 0 & 0.12 & 0.12 & $\alpha_{L}^{\prime}$ & & Fukuda et al. ${ }^{13}$ \\
\hline Belite & & & $\sim 5$ & & & & & & $\alpha_{H}^{\prime}$ & & Mumme et al. ${ }^{12}$ \\
\hline Belite & 62.14 & 29.71 & 6.47 & 0 & 0.63 & 0 & 0.13 & 0.25 & $\alpha_{L}^{\prime}$ & & Fukuda et al. ${ }^{13}$ \\
\hline Belite & 61.81 & 28.64 & 8.30 & 0 & 0.69 & 0 & 0.17 & 0.20 & $\alpha_{L}^{\prime}$ & & Fukuda et al. ${ }^{13}$ \\
\hline Belite & 53.42 & 28.62 & 8.45 & 0 & 9.50 & 0 & 0 & 0 & $\alpha>\alpha$ & & Benarchid et al. ${ }^{15}$ \\
\hline Belite $^{\star}$ & $\begin{array}{l}61.9- \\
63.0\end{array}$ & $\begin{array}{l}26.3- \\
28.5\end{array}$ & $\begin{array}{l}7.1- \\
11.8\end{array}$ & 0 & 0 & 0 & 0 & 0 & $\alpha_{H}^{\prime}$ & & Saalfeld et al. $^{9}$ \\
\hline Belite & & & $\sim 10$ & & & & & & $\alpha_{H}^{\prime}$ & & Mumme et al. ${ }^{12}$ \\
\hline Belite & 60.04 & 21.94 & 17.15 & 0 & 0.61 & 0 & 0.18 & 0.41 & $\alpha$ & & Fukuda et al. ${ }^{13}$ \\
\hline Alite & 73.26 & 26.08 & 0.31 & 0.35 & 0 & 0 & 0 & 0 & - & M3 & Diouri et al. ${ }^{14}$ \\
\hline Alite & 72.84 & 25.84 & 0.62 & 0.69 & 0 & 0 & 0 & 0 & - & M3 & Diouri et al. ${ }^{14}$ \\
\hline Alite & 71.57 & 25.12 & 1.56 & 1.73 & 0 & 0 & 0 & 0 & $\beta$ & M3 & Diouri et al. ${ }^{14}$ \\
\hline Alite & 69.45 & 23.92 & 3.14 & 3.48 & 0 & 0 & 0 & 0 & $\beta$ & - & Diouri et al. ${ }^{14}$ \\
\hline Alite & 67.30 & 22.70 & 4.73 & 5.26 & 0 & 0 & 0 & 0 & $\beta=\alpha^{\prime}$ & - & Diouri et al. ${ }^{14}$ \\
\hline
\end{tabular}

$\S \beta>\gamma$ means that $\beta$ is major than $\gamma$ polymorph. $\beta=\alpha^{\prime}$ means that $\beta$ and $\gamma$ polymorphs are in equal quantities.

^ Four single crystals investigated by EMPA, lower and upper contents are mentioned here. 


\section{Experimental procedure}

\section{(1) Sample preparation}

The tricalcium silicate samples were doped between 0 and $0.9 \mathrm{wt} \% \% \mathrm{P}_{2} \mathrm{O}_{5}$. The starting powders were tricalcium phosphate $\mathrm{Ca}_{3} \mathrm{P}_{2} \mathrm{O}_{8}$ (VWR, VWR Prolabo reference 22420237, Fontenay sous Bois, France) and tricalcium silicate $\mathrm{C}_{3} \mathrm{~S}$ (with a specific area of $370 \mathrm{~m}^{2} \cdot \mathrm{kg}^{-1}$, synthesized by G. Gasecki, CTG, Italcementi Group). Preliminary, $\mathrm{Ca}_{3} \mathrm{P}_{2} \mathrm{O}_{8}$ powder was passed through a $80 \mu \mathrm{m}$ sieve until refusal. For each doped sample, the experimental procedure was as follows. First, the dried powders were mixed together in stochiometric quantities. In a further step, the mixture was passed through a $250 \mu \mathrm{m}$ sieve until refusal. This operation was repeated five times. Then, in order to get pellets, 10 grams of the resulting powders were uniaxially pressed during 25 seconds; the uniaxial pressure was 5 and 7 tons for 0 - 0.5 and $0.7-0.9$ wt. $\% \mathrm{P}_{2} \mathrm{O}_{5}$ doped samples respectively. The pellets were sintered in an electrical furnace with a heating rate of $30^{\circ} \mathrm{C} / \mathrm{min}$, held at $1450^{\circ} \mathrm{C}$ during $6.5 \mathrm{~h}$ and then quenched in air, in order to avoid $\mathrm{C}_{3} \mathrm{~S}$ retrogradation into $\mathrm{C}_{2} \mathrm{~S}$ and free lime (referred to as $\mathrm{f}-\mathrm{CaO}$ ). The chemical homogenization of the mixtures was optimized by grinding the resulting pellets, pressed and sintered one time again.

In order to control the exact chemical composition and the free-lime content of the synthesized samples, the sintered pellets were ground with a mean particle size of $80 \mu \mathrm{m}$ required for both the X-ray fluorescence and the ethylene glycol methods. The chemical composition (wt. \%), given in Table II, was determined by X-ray fluorescence (XRF, Model PW2440, PANalytical, Almelo, the Netherlands). The unreacted lime (free lime, f-CaO) was determined according to the standard ethylene glycol extraction method ${ }^{17}$. The results are summarized in Table III. A small decrease is observed in the range $0-0.5$ wt. $\% \mathrm{P}_{2} \mathrm{O}_{5}$ and a strong increase above $0.5 \mathrm{wt}$. $\% \mathrm{P}_{2} \mathrm{O}_{5}$.

Table II. Chemical analysis (XRF) for the $\mathrm{C}_{3} \mathrm{~S}$ samples doped with varying $\mathrm{P}_{2} \mathrm{O}_{5}$ contents. In the following of the text, the $\mathrm{P}_{2} \mathrm{O}_{5}$ contents of the samples are referred to as 0.1 until 0.9 wt. $\%\left(7^{\text {th }}\right.$ column)

\begin{tabular}{ccccccc}
\hline $\begin{array}{c}\mathrm{CaO} \\
\text { (wt. \%) }\end{array}$ & $\begin{array}{c}\mathrm{SiO}_{2} \\
\text { (wt. \%) }\end{array}$ & $\begin{array}{c}\mathrm{Al}_{2} \mathrm{O}_{3} \\
\text { (wt. \%) }\end{array}$ & $\begin{array}{c}\mathrm{Fe}_{2} \mathrm{O}_{3} \\
\text { (wt. \%) }\end{array}$ & $\begin{array}{c}\mathrm{P}_{2} \mathrm{O}_{5} \\
\text { (wt. \%) }\end{array}$ & $\begin{array}{c}\text { Loss on ignition } \\
\text { (wt. \%) }\end{array}$ & $\begin{array}{c}\mathrm{P}_{2} \mathrm{O}_{5} \text { range } \\
\text { (wt. \%) }\end{array}$ \\
\hline 73.44 & 25.98 & 0.09 & 0.02 & 0.00 & 0.47 & 0.0 \\
73.36 & 25.88 & 0.11 & 0.02 & 0.09 & 0.54 & 0.1 \\
73.25 & 25.75 & 0.09 & 0.01 & 0.31 & 0.59 & 0.3 \\
73.17 & 25.65 & 0.10 & 0.00 & 0.50 & 0.58 & 0.5 \\
73.18 & 25.53 & 0.10 & 0.00 & 0.71 & 0.47 & 0.7 \\
73.14 & 25.39 & 0.09 & 0.01 & 0.92 & 0.45 & 0.9 \\
\hline
\end{tabular}


Table III. Free lime contents (f-CaO) in the $\mathrm{C}_{3} \mathrm{~S}$ samples doped with varying $\mathrm{P}_{2} \mathrm{O}_{5}$ contents. The experimental uncertainty was established at $16 \%$ in a range of observed values

\begin{tabular}{ccccccc}
\hline $\mathrm{P}_{2} \mathrm{O}_{5}$ (wt. \%) & 0.0 & 0.1 & 0.3 & 0.5 & 0.7 & 0.9 \\
$\mathrm{f}-\mathrm{CaO}$ (wt. \%) & $0.8 \pm 0.1$ & $0.6 \pm 0.1$ & $0.4 \pm 0.1$ & $0.8 \pm 0.1$ & $1.5 \pm 0.2$ & $2.2 \pm 0.4$ \\
\hline
\end{tabular}

\section{(2) Structural analysis: $X$-ray powder diffraction data collection and Rietveld refinements}

Sintered pellets were ground down to $40 \mu \mathrm{m}$ mean particle size. X-ray powder diffraction was performed under the same conditions for all the samples. An X-ray powder diffractometer (Model X'Pert PRO MPD, PANalytical, Almelo, the Netherlands) in Bragg Brentano geometry $(\theta / \theta)$ was used combined with a fast detector based on real time multiple strip (RTMS) technology (X'Celerator). For the purpose of an unambiguous phase identification, the powder pattern of the sample with the highest $\mathrm{P}_{2} \mathrm{O}_{5}$ concentration $(0.9 \%)$ was also taken at higher resolution with a diffractometer (X'Pert PRO MPD, PANalytical), equipped with an incident beam monochromator and a fast detector (X'Celerator). Hereafter these two experimental setups -low and high resolutionare respectively referred to LR and HR. All the experimental settings and conditions are summarized in Table IV.

Table IV. Experimental settings for XRD analysis for all the samples (LR) and for the 0.9 wt. \% $\mathrm{P}_{2} \mathrm{O}_{5}$ doped $\mathrm{C}_{3} \mathrm{~S}$ sample (HR)

\begin{tabular}{ccc}
\hline Experimental setup & $\mathrm{LR}$ & $\mathrm{HR}$ \\
\hline Tube & $\mathrm{Cu}$ & $\mathrm{Cu}$ \\
Generator settings $(\mathrm{kV}, \mathrm{mA})$ & 45,40 & 45,40 \\
Incident filter & $\mathrm{Ni}$ & $\mathrm{None}$ \\
Incident monochromator & none & curved Ge $(111)$ \\
Incident radiation & $\mathrm{Cu} \mathrm{K}_{\alpha 1, \alpha 2}$ & $\mathrm{Cu} \mathrm{K}_{\alpha 1}$ \\
Incident Soller slits (rad) & 0.04 & 0.02 \\
Incident divergence slit $\left(^{\circ}\right)$ & 0.25 & 0.5 \\
Mask (mm) & 10 & 10 \\
Incident anti-scattering slit $\left(^{\circ}\right)$ & 0.5 & 1 \\
Sample holder & spinning & spinning \\
Anti-scattering slit (mm) & 5 & 5 \\
Soller slits (rad) & 0.04 & 0.02 \\
Scan type & 2.122 & 2.022 \\
${\text { Range }\left({ }^{\circ} \text { Celerator } 2 \theta\right)}_{\text {Step size }\left({ }^{\circ} 2 \theta\right)}$ & $10-70$ & $10-70$ \\
Scan step time (hour) & 0.0167 & 0.0084 \\
& 0.5 & 13 \\
\hline
\end{tabular}

Phase identifications were performed using EVA software (version 13, Bruker-AXS, Karlsruhe, Germany, 1996-2007) and JCPDS - International Centre for Diffraction Data ${ }^{\circledR}$ Powder Diffraction File (PDF-2, JCPDS-ICDD, Newtown Square, PA). Rietveld refinements were 
performed using TOPAS 3 software (TOPAS, version 3, Bruker-AXS, Karlsruhe, Germany, 19962007) based on the fundamental parameters approach ${ }^{20}$.

\section{(3) Microstructural analysis: SEM observations coupled to EDS and Castaing microprobe}

The microstructural and morphological features were observed on polished sections of the pellets, previously embedded in an epoxy resin by vacuum impregnation, and then coated with a layer of carbon to avoid charging under the electron beam.

In order to determine the distribution of phosphorus in the doped tricalcium silicate samples, a scanning electron microscope (SEM) equipped with a field emission gun (Model LEO 1530, Carl Zeiss SMT, Oberkochen, Germany), coupled to an energy dispersion X-ray analysis, EDS (Model Prism IMIX, Princeton Gamma-Tech Instruments, Princeton, USA), was used. To perform a local chemical analysis of each sample, more than 100 locations were analyzed using EDS at $15 \mathrm{kV}$ accelerating voltage. The secondary electron images (predominant topographic contrast) were taken using $8 \mathrm{kV}$ accelerating voltage.

To precise the localisation of phosphorus in samples, X-ray maps were accumulated with a Castaing microprobe (Model SX 100, CAMECA, Gennevilliers, France) equipped with WDS spectrometers. The WDS analyses were performed at $15 \mathrm{kV}$ with a $40 \mathrm{nA}$ beam current. The elements considered were calcium, silicon, oxygen and phosphorus.

\section{Results}

\section{(1) $X$-ray diffraction analysis}

(A) Phase identification: Pure $\mathrm{C}_{3} \mathrm{~S}$ sample contains the expected $\mathrm{T}_{1}$ triclinic polymorph (Fig. 1), with its two characteristic triplets (Fig. 2) in the two angular windows $2 \theta_{\mathrm{Cu}}=31-33.5^{\circ}$ and $2 \theta_{\mathrm{Cu}}=51-52.3^{\circ}$ respectively referred to as W3 and W5 in the study of Courtial et al..$^{21}$. The positions of the $\mathrm{C}_{3} \mathrm{~S}$ Bragg lines are well reproduced using the $\mathrm{C}_{3} \mathrm{~S}$ triclinic unit cell parameters of the powder diffraction study of Regourd et al. ${ }^{22,23}$. The $\mathrm{C}_{3} \mathrm{~S}$ Bragg lines are indexed on the basis of the structural model determined by Golovastikov et al. ${ }^{24,25}$. The indexation of the lines of the two triplets of the W3 and W5 windows is given by Fig. 2. The f-CaO Bragg lines ${ }^{26}$ are observed, but with a very low intensity. The more intense line (200) at $2 \theta_{\mathrm{Cu}}=37.36^{\circ}$ is indicated by the arrow in Fig.1. 


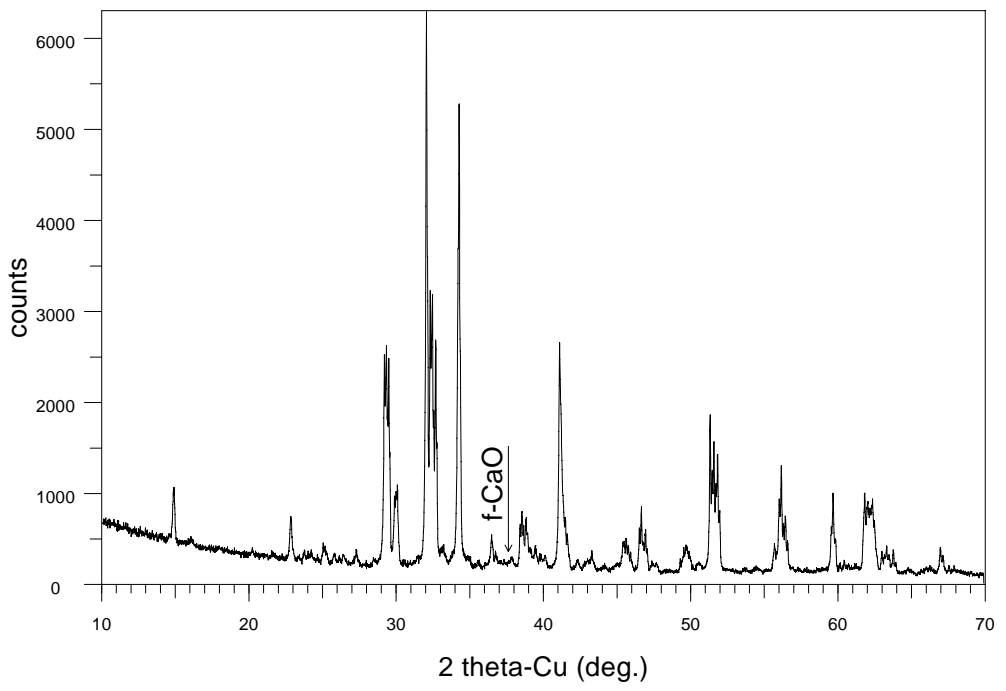

Fig. 1. X-ray diffraction pattern of the pure $\mathrm{C}_{3} \mathrm{~S}$ sample $\left(\mathrm{T}_{1}\right.$ triclinic polymorph) with the $\mathrm{LR}$ experimental setup. The arrow shows the characteristic line (200) of free lime (f-CaO) at $2 \theta_{\mathrm{Cu}}=37.36^{\circ}$.

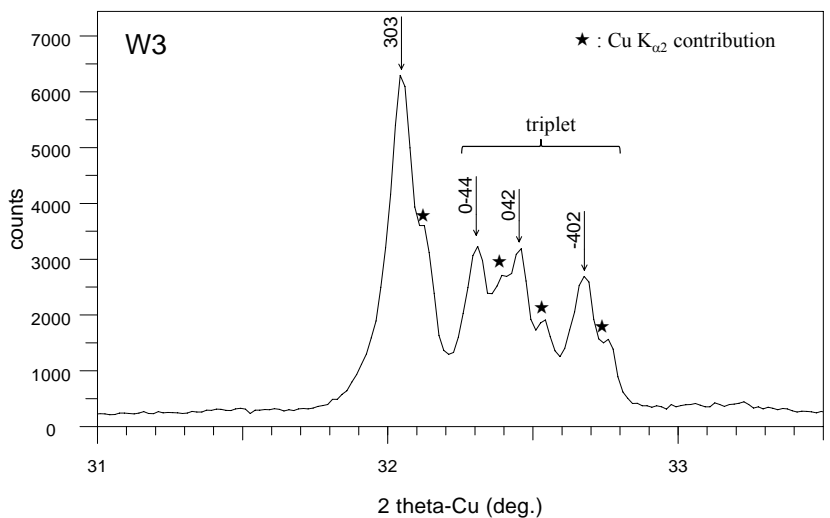

(a)

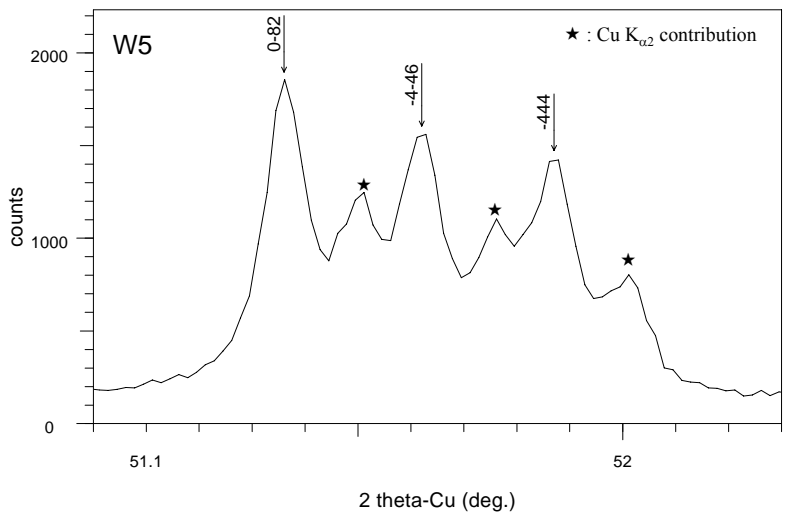

(b)

Fig. 2. The two characteristic triplets $(0-44,042,-402)$ and $(0-82,-4-46,-444)$ in the W3 and W5 angular windows of Fig. 1. (a) W3: $2 \theta_{\mathrm{Cu}}=31-33.5^{\circ}$; (b) W5: $2 \theta_{\mathrm{Cu}}=51-52.3^{\circ}$. The characteristic Bragg lines are indexed on the basis of the $T_{1}$ model of Golovastikov.

The evolution of the XRD patterns with increasing $\mathrm{P}_{2} \mathrm{O}_{5}$ content is given in Fig. 3a. Whatever the $\mathrm{P}_{2} \mathrm{O}_{5}$ content, the same triclinic $\mathrm{T}_{1}$ type of polymorph is always observed. Below 0.5 wt. $\% \mathrm{P}_{2} \mathrm{O}_{5}$, the whole pattern is explained using the same phases as in the pure sample. From 0.5 wt. $\% \mathrm{P}_{2} \mathrm{O}_{5}$ upwards, rather intense and broad peaks are observed, the two more intense of them being located respectively between $2 \theta_{\mathrm{Cu}}=30.9-31.3^{\circ}$ and $2 \theta_{\mathrm{Cu}}=32.9-33.1^{\circ}$ (inside the W3 angular window) as shown by arrows in Fig. 3(a, b-c). The Bragg line (001) of portlandite ${ }^{27}$ $\mathrm{Ca}(\mathrm{OH})_{2}$ is also identified at $2 \theta_{\mathrm{Cu}}=17.98^{\circ}$, with an increasing intensity along with $\mathrm{P}_{2} \mathrm{O}_{5}$ content 
(Fig. 3d) ${ }^{\text {}}$. Therefore, in our samples (detailed in $\S$ III.1.C), f-CaO is in fact hydrated into portlandite. The broadening of the portlandite lines is related to a nanometric grain size.

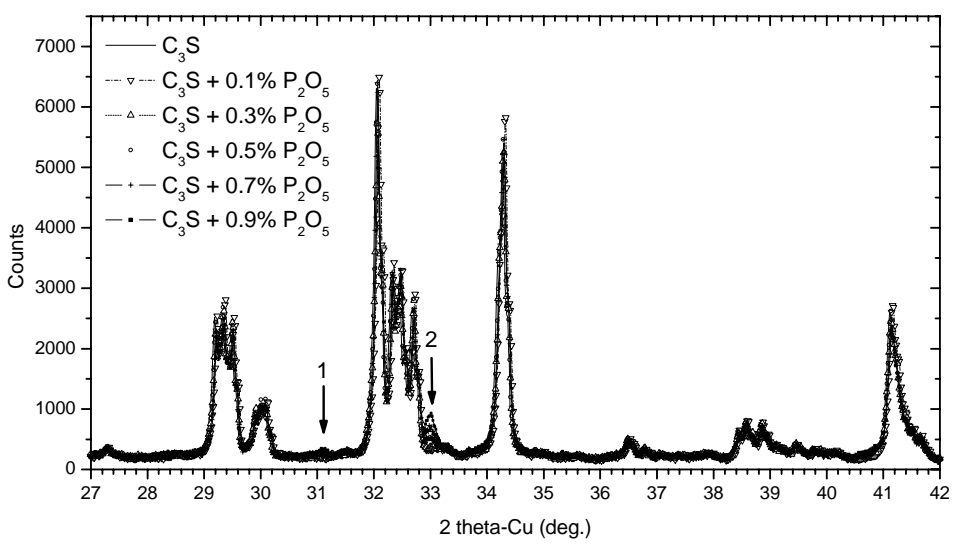

(a)

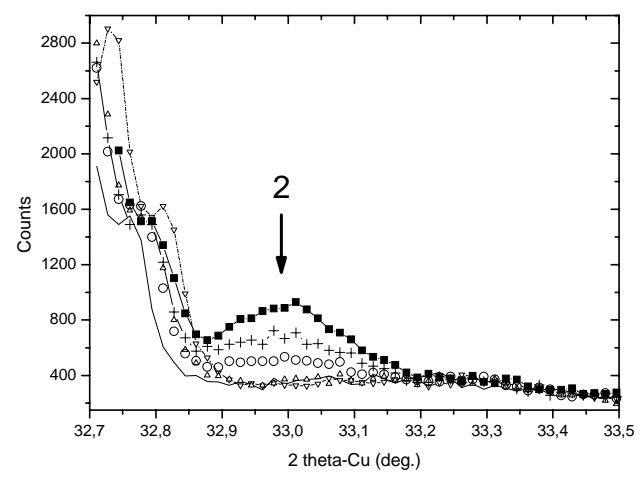

(c)

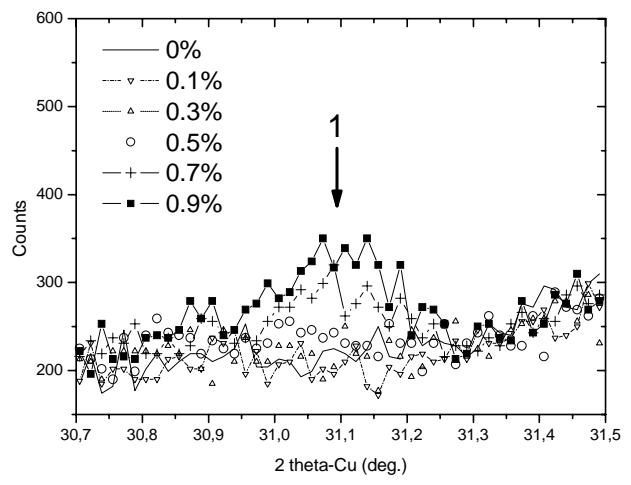

(b)

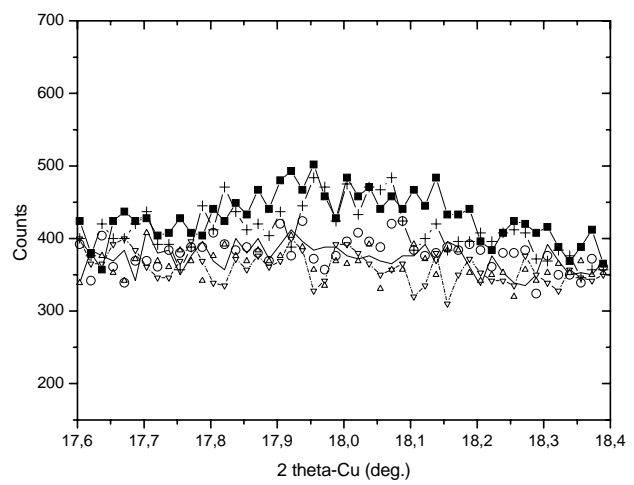

(d)

Fig. 3. (a) XRD patterns of the samples doped with various $P_{2} O_{5}$ contents (0 - 0.9 wt. \% $\left.P_{2} O_{5}\right)$ : $L R$ experimental setup. The arrows $(1$ and 2$)$ show the more intense new peaks, which appear above 0.3 wt. $\% \mathbf{P}_{2} \mathrm{O}_{5}$. (b) $2 \theta_{\mathrm{Cu}}=$ 30.7 - $31.5^{\circ}$; (c) $2 \theta_{\mathrm{Cu}}=32.7-33.5^{\circ}$; (d) Bragg line (001) of portlandite about $2 \theta_{\mathrm{Cu}}=17.98^{\circ}$.

The next point is now the origin of the broadening of the two peaks 1 and 2 of Fig. 3, not observed in the pure sample, and therefore referred to as the "new peaks" in the following. An additional XRD experiment was performed using higher resolution conditions (cf. Table IV, HR experimental setup) on the sample with the highest impurity content $\left(0.9\right.$ wt. $\left.\% \mathrm{P}_{2} \mathrm{O}_{5}\right)$. Figure 4 superimposes the data in the W3 window for the LR and HR experimental setups. In order to perform the comparison, the $\mathrm{K}_{\alpha 2}$ contribution of the LR pattern was previously subtracted by a numerical treatment using EVA software. Two distinct peaks in the $2 \theta_{\mathrm{Cu}}=32.9-33.1^{\circ}$ range are

¥ The Bragg line $(-211)$ of $\mathrm{C}_{3} \mathrm{~S}$ (intensity $=0.2 \%$ ) can be neglected compared to the $\mathrm{Ca}(\mathrm{OH})_{2}$ one (intensity $=72 \%)$. 
actually clearly observed in the HR experiment. The line width of these peaks is still higher than that of the $\mathrm{C}_{3} \mathrm{~S}$ lines of the same pattern. Such a peak broadening may be due either to a size-effect, and/or to a distribution of various chemical composition and/or internal strain.

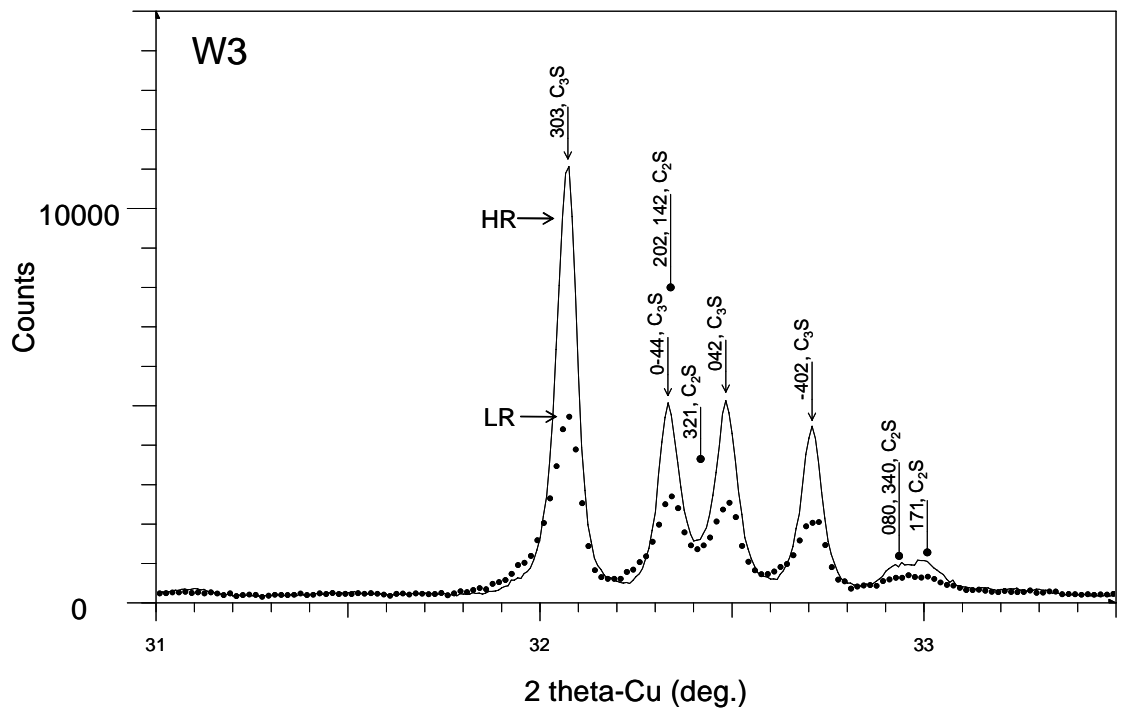

Fig. 4. W3 window: XRD patterns of the sample doped with 0.9 wt. $\% \mathrm{P}_{2} \mathrm{O}_{5}$ : LR and HR experimental setups. In the $L R$ case, a data treatment was performed in order to subtract the $K_{\alpha 2}$ contribution. The vertical arrows and points show the indexation of the more intense Bragg lines of pure $C_{3} S$ and $\alpha^{\prime}{ }_{H^{-}} C_{2} S$ polymorphs respectively.

The presence of this experimental doublet about $2 \theta_{\mathrm{Cu}}=33^{\circ}$ makes easier the phase identification of the additional phase. A systematic phase research leads to the identification of the structure proposed by Saalfeld and Klaska, ${ }^{9,28}$ : a compound $6_{2} \mathrm{C}_{2} \mathrm{~S} .1 \mathrm{C}_{3} \mathrm{P}$ (i.e. about 10.6 wt. \% $\mathrm{C}_{3} \mathrm{P}$ ), displaying a superstructure of the $\alpha^{\prime}{ }_{\mathrm{H}}-\mathrm{C}_{2} \mathrm{~S}$ polymorph. The doublet is indexed with the Bragg lines doublet (080 and 340 at $d=0.27136 \mathrm{~nm})$ and the 171 Bragg line $(\mathrm{d}=0.270452 \mathrm{~nm})$ of the structural model. The other intense lines $(142,202,321)$ of $\alpha^{\prime}{ }^{\prime}-C_{2} S$ are mixed with strong $\mathrm{C}_{3} \mathrm{~S}$ lines (Fig. 4). The visual identification described here is based on the detection of two or three Bragg lines: the only lines clearly separated from the others. However, in the next paragraph (III.1.B), this result will be validated on the whole pattern using Rietveld analysis. To conclude, the doublet about $2 \theta_{\mathrm{Cu}}=33^{\circ}$ containing the intense Bragg lines of the Saalfeld structure, and none of the intense $\mathrm{C}_{3} \mathrm{~S}$ lines, is a useful key for a visual identification of the $\alpha^{\prime}{ }_{\mathrm{H}}-\mathrm{C}_{2} \mathrm{~S}$ phase.

(B) Rietveld quantification: For the series of doped samples, the set of XRD data collected with the LR experimental setup was systematically analyzed quantitatively using the Rietveld 
methodology $y^{29,30}$. The refined parameters were scale factors, sample displacement, background as Chebychev polynomial of the fifth order, crystallite size and unit cell parameters of all the phases. The atomic positions and temperature factors were kept constant in all the crystal structures.

The Saalfeld structure of the $\alpha^{\prime}{ }_{\mathrm{H}}-\mathrm{C}_{2} \mathrm{~S}$ phase ${ }^{9}$, determined by the authors using single crystal studies, introduces a unit cell with so-called $\mathrm{TO}_{4}$ tetrahedra instead of $\mathrm{SiO}_{4}$ tetrahedra ${ }^{\S}$. Powder diffraction is much less sensitive than single crystal diffraction to such details. Therefore, we use here a simplified model: all these tetrahedra are taken only as $\mathrm{SiO}_{4}$ tetrahedra. The four following structural models are used:

- $\mathrm{C}_{3} \mathrm{~S}$ : model of Golovastikov et al. ${ }^{24}$,

- $\mathrm{CaO}$ lime: model of Wyckoff ${ }^{31}(\mathrm{NaCl}$ structural type),

- portlandite: model of Petch ${ }^{32}$,

$-\alpha{ }^{\prime} \mathrm{C}_{2} \mathrm{~S}$ : the Saalfeld and Klaska ${ }^{9}$ simplified model as mentioned above.

The $\alpha{ }^{\prime}-C_{2} \mathrm{~S}$ phase is taken into account only from $0.3 \mathrm{wt} . \% \mathrm{P}_{2} \mathrm{O}_{5}$ upwards.

The good agreement of the refinements validates the presence of these four phases. Figure 5 reproduces the refinement for the most doped sample and shows the good treatment of the experimental doublet of Bragg lines at $2 \theta_{\mathrm{Cu}}=33^{\circ}$ (W3 window).

As the $\mathrm{P}_{2} \mathrm{O}_{5}$ content increases from 0.3 wt. $\% \mathrm{P}_{2} \mathrm{O}_{5}$ upwards, the quantitative phase analysis (Fig. 5 and Table V) shows a diminution of the amount of $\mathrm{C}_{3} \mathrm{~S}$ phase correlated with an increase of the $\alpha{ }^{\prime}{ }^{-} \mathrm{C}_{2} \mathrm{~S}, \mathrm{f}-\mathrm{CaO}$ and portlandite phases. It suggests a decomposition of $\mathrm{C}_{3} \mathrm{~S}$ into $\alpha{ }^{\prime}{ }_{\mathrm{H}}-\mathrm{C}_{2} \mathrm{~S}$ and $\mathrm{f}-$ $\mathrm{CaO}$.

No significant effect on the evolution of the unit cell parameters of $\mathrm{C}_{3} \mathrm{~S}$ is detected. Due to the unfiltered $\mathrm{K}_{\alpha 1, \alpha 2}$ radiation and to the very low concentration of the $\alpha^{\prime}{ }_{\mathrm{H}}-\mathrm{C}_{2} \mathrm{~S}$ phase, the resolution is not sufficient to discuss a meaningful evolution of the unit cell parameters of the $\alpha^{\prime}{ }_{\mathrm{H}^{-}} \mathrm{C}_{2} \mathrm{~S}$ phase (Table VI). However, from 0.5 wt. $\% \mathrm{P}_{2} \mathrm{O}_{5}$ upwards, the unit cell parameters are close to those of Saalfeld and Klaska ${ }^{9}$.

In conclusion, as already shown by previous studies (cf. Table I), phosphorus stabilises the $\alpha^{\prime}{ }^{-} \mathrm{C}_{2} \mathrm{~S}$ phase, hereafter referred to as the $\alpha^{\prime}{ }^{-} \mathrm{C}_{2} \mathrm{~S}(\mathrm{P})$ phase.

\footnotetext{
$\S \S$ These $\mathrm{TO}_{4}$ tetrahedra have to be understood as a weighted average between the $\mathrm{SiO}_{4}$ and $\mathrm{PO}_{4}$ tetrahedra. The problem with such an average is the electric balance due to the replacement of $\mathrm{Si}^{4+}$ ions by $\mathrm{P}^{5+}$ ions. In order to keep the electric neutrality $\mathrm{Ca}^{2+}$ vacancies are introduced using a population $\mathrm{x}_{\mathrm{Ca}}<1$ for some calcium ions.
} 


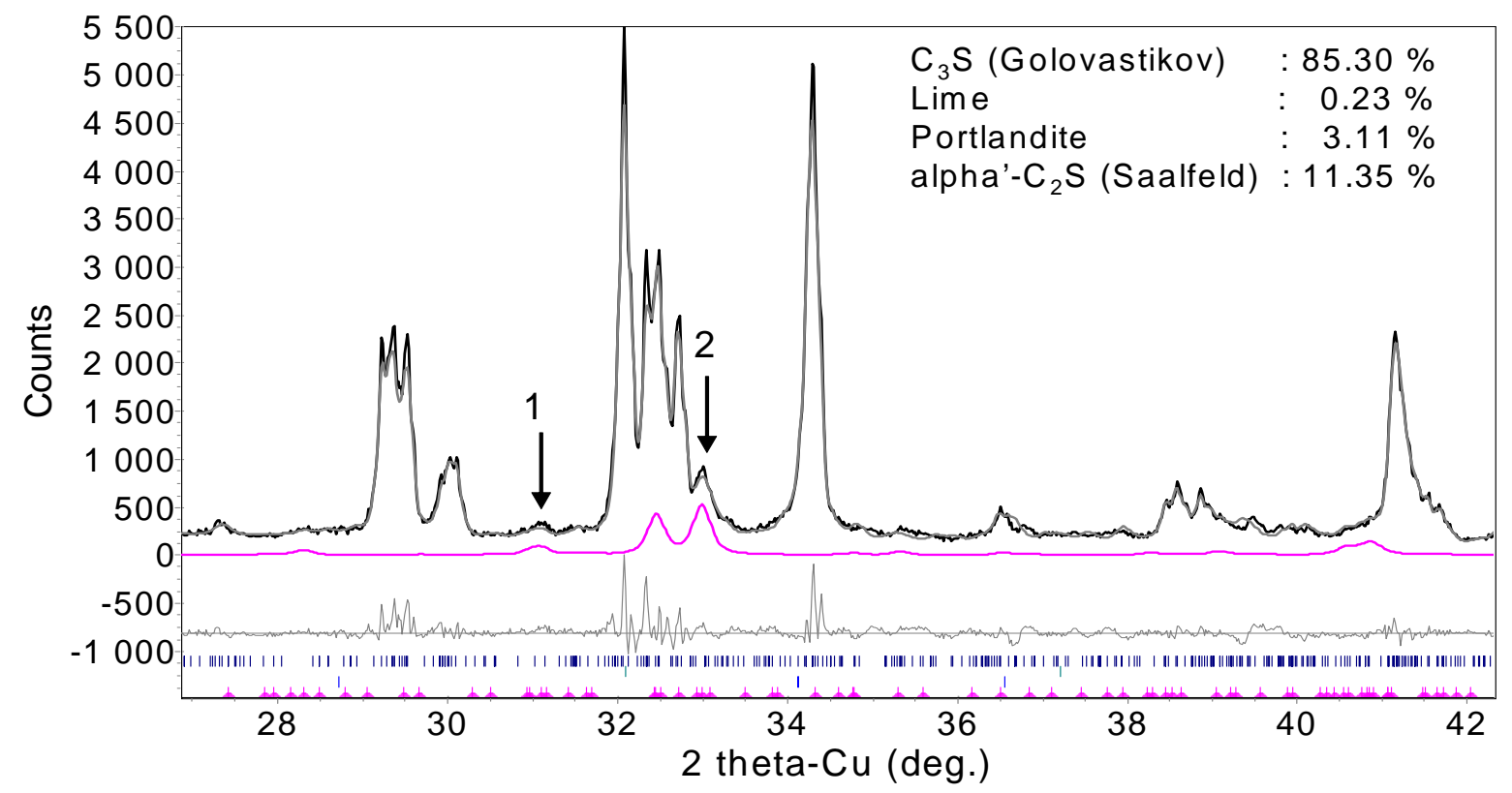

Fig. 5. Rietveld refinement of XRD data of the sample doped with 0.9 wt. $\% \mathrm{P}_{2} \mathrm{O}_{5}$ (LR experimental setup), with the model of Golovastikov for $\mathrm{C}_{3} \mathrm{~S}$ and the model of Saalfeld simplified here for $\alpha^{\prime}{ }_{\mathrm{H}}-\mathrm{C}_{2} \mathrm{~S}$. The arrows mark the characteristic peaks of $\alpha^{\prime}{ }^{-} \mathrm{C}_{2} \mathrm{~S}$ (cf. figure 3a). From top to bottom are represented: the observed (black curve) and calculated (grey) XRD patterns, the calculated contribution of $\alpha^{\prime}{ }_{\mathrm{H}^{-}} \mathrm{C}_{2} \mathrm{~S}$ (red line), the difference plot between observed and calculated data, the Bragg reflection markers. From top to bottom, these markers correspond to $\mathrm{C}_{3} \mathrm{~S}$, lime, portlandite and $\alpha^{\prime}{ }_{\mathrm{H}^{-}} \mathrm{C}_{2} \mathrm{~S}$.

Table V. Rietveld analyses of the XRD data (LR experimental setup) of the $C_{3} S$ doped samples: quantitative phase analyses and resulting criteria of fits (goodness of fit - GOF - and $R_{\text {Bragg) }}$

\begin{tabular}{ccccccc}
\hline $\mathrm{P}_{2} \mathrm{O}_{5}$ (wt. \%) & 0.0 & 0.1 & 0.3 & 0.5 & 0.7 & 0.9 \\
\hline $\mathrm{C}_{3} \mathrm{~S}($ wt. \%) & $99.3(12)$ & $98.65(20)$ & $96.23(39)$ & $93.07(38)$ & $89.72(34)$ & $85.30(31)$ \\
$\alpha^{\prime}{ }^{-} \mathrm{C}_{2} \mathrm{~S}($ wt. \%) & - & - & $2.75(35)$ & $5.50(34)$ & $7.92(30)$ & $11.35(27)$ \\
$\mathrm{CaO}$ (wt. \%) & $0.44(11)$ & $0.36(11)$ & $0.36(10)$ & $0.310(98)$ & $0.316(99)$ & $0.232(81)$ \\
Portlandite (wt. \%) & $0.266(59)$ & $0.99(17)$ & $0.66(17)$ & $1.11(16)$ & $2.05(16)$ & $3.11(10)$ \\
$\mathrm{GOF}$ & 2.06 & 2.12 & 1.95 & 1.96 & 2.01 & 1.92 \\
$\mathrm{R}_{\text {Bragg }}\left(\mathrm{C}_{3} \mathrm{~S}\right)$ & 4.79 & 4.88 & 4.06 & 4.12 & 4.76 & 4.26 \\
$\mathrm{R}_{\text {Bragg }}\left(\alpha{ }^{\prime}-\mathrm{C}_{2} \mathrm{~S}\right)$ & - & - & 2.67 & 3.11 & 3.83 & 3.81 \\
$\mathrm{R}_{\text {Bragg }}(\mathrm{CaO})$ & 3.29 & 3.11 & 2.50 & 2.51 & 2.49 & 1.78 \\
$\mathrm{R}_{\text {Bragg }}$ (Portlandite) & 3.23 & 3.19 & 2.67 & 2.55 & 2.38 & 2.66 \\
\hline
\end{tabular}

Table VI. Rietveld analyses of the XRD data (LR experimental setup) of the $\mathrm{C}_{3} \mathrm{~S}$ doped samples: evolution of the unit cell parameters of doped $\alpha^{\prime}{ }^{-} \mathrm{C}_{2} \mathrm{~S}$ phase. Comparison with the single crystal study of Saalfeld

\begin{tabular}{|c|c|c|c|c|c|c|}
\hline $\begin{array}{c}\text { Doped } \alpha^{\prime}{ }^{-} C_{2} S \\
\text { phase }\end{array}$ & $\begin{array}{l}\mathrm{P}_{2} \mathrm{O}_{5} \\
\text { (wt. \%) }\end{array}$ & $\begin{array}{c}\mathrm{a} \\
(\mathrm{nm})\end{array}$ & $\begin{array}{c}\mathrm{b} \\
(\mathrm{nm})\end{array}$ & $\begin{array}{c}\mathrm{c} \\
(\mathrm{nm})\end{array}$ & $\begin{array}{c}\alpha=\beta=\gamma \\
\text { (deg.) }\end{array}$ & $\begin{array}{c}\mathrm{V} \\
\left(\mathrm{nm}^{3}\right)\end{array}$ \\
\hline This study & 0.3 & $0.9385(18)$ & $2.1488(38)$ & $0.6815(13)$ & 90 & $1.3744(44)$ \\
\hline This study & 0.5 & $0.939(15)$ & $2.1714(29)$ & $0.68143(66)$ & 90 & $1.3893(32)$ \\
\hline This study & 0.7 & $0.93918(61)$ & $2.1740(12)$ & $0.68144(30)$ & 90 & $1.3913(14)$ \\
\hline This study & 0.9 & $0.93930(36)$ & $2.17356(72)$ & $0.68123(18)$ & 90 & $1.39081(79)$ \\
\hline Saalfeld and Klaska ${ }^{9}$ & $\sim 7-12$ & $0.940(8)$ & $2.171(2)$ & $0.683(3)$ & 90 & $1.39382(5)$ \\
\hline
\end{tabular}




\section{(2) Microstructural and chemical analysis (SEM/EDS and EMPA)}

Figure 6 shows secondary electron images and microanalyses of pure $\mathrm{C}_{3} \mathrm{~S}$ (Fig. 6a) and $\mathrm{C}_{3} \mathrm{~S}$ doped with 0.1 and 0.3 wt. $\% \mathrm{P}_{2} \mathrm{O}_{5}$ (Figs. 6b-c).

(A) Pure sample: Figure 6a shows (in grey) the grain clusters of the sample. EDS analyses made in several parts of the sample (points 1 and 2 in Fig. 6a) show calcium, silicon, oxygen and carbon (coating) only. Additional EMPA X-ray maps (Fig. 7a) attest the chemical homogeneity of the sample. Thus, according to XRD analysis, the sample contains only the expected pure $\mathrm{C}_{3} \mathrm{~S}$ phase.

(B) Doped samples: From 0.1 wt. $\% \mathrm{P}_{2} \mathrm{O}_{5}$ upwards, secondary electron images show several levels of grey. Up to 0.9 wt. $\% \mathrm{P}_{2} \mathrm{O}_{5}$, a phase with a very smooth appearance (no porosity, no polishing lines and no cracking) covers more and more the $\mathrm{C}_{3} \mathrm{~S}$ grain clusters. It appears in clearer grey than that of $\mathrm{C}_{3} \mathrm{~S}$ phase (see Fig. 6b-c, labels 4, 5 and 7). The contrast between the two phases is optimized when decreasing the voltage (from 15 to $8 \mathrm{kV}$ ), which suggests the presence of a thin layer covering $\mathrm{C}_{3} \mathrm{~S}$ grain clusters. EDS analyses in several regions of this smooth phase, as illustrated in Fig. 6b-c with the spectra numbered 4, 5 and 7, show the presence of $\mathrm{Ca}, \mathrm{Si}, \mathrm{O}$ and $\mathrm{P}$ in this layer. No phosphorus is detected in $\mathrm{C}_{3} \mathrm{~S}$ darker grain clusters (see Fig 6b-c, labels 3 and 6). Above 0.5 wt. $\% \mathrm{P}_{2} \mathrm{O}_{5}$, free lime clusters dispersed in the whole sample are also observed in dark grey (their characteristic cubic morphology can be observed in Fig. 6c, label 8). Additional X-ray maps with Castaing microprobe were performed in order to precise the localization of phosphorus. Figure $7 \mathrm{~b}$ shows the case of the $\mathrm{C}_{3} \mathrm{~S}$ sample doped with 0.3 wt. $\% \mathrm{P}_{2} \mathrm{O}_{5}$ : phosphorus clearly accumulates in grain boundaries of $\mathrm{C}_{3} \mathrm{~S}$ grains. As the amount of phosphorus increases, a thin layer rich in phosphorus progressively covers the $\mathrm{C}_{3} \mathrm{~S}$ grain clusters, as was seen in SEM observations. This new layer is attributed to the phase observed in our XRD study (III.1.B), that we attribute to the retrogradation of the $\mathrm{C}_{3} \mathrm{~S}$ into $\alpha^{\prime}{ }_{\mathrm{H}}-\mathrm{C}_{2} \mathrm{~S}(\mathrm{P})$ and free lime. 

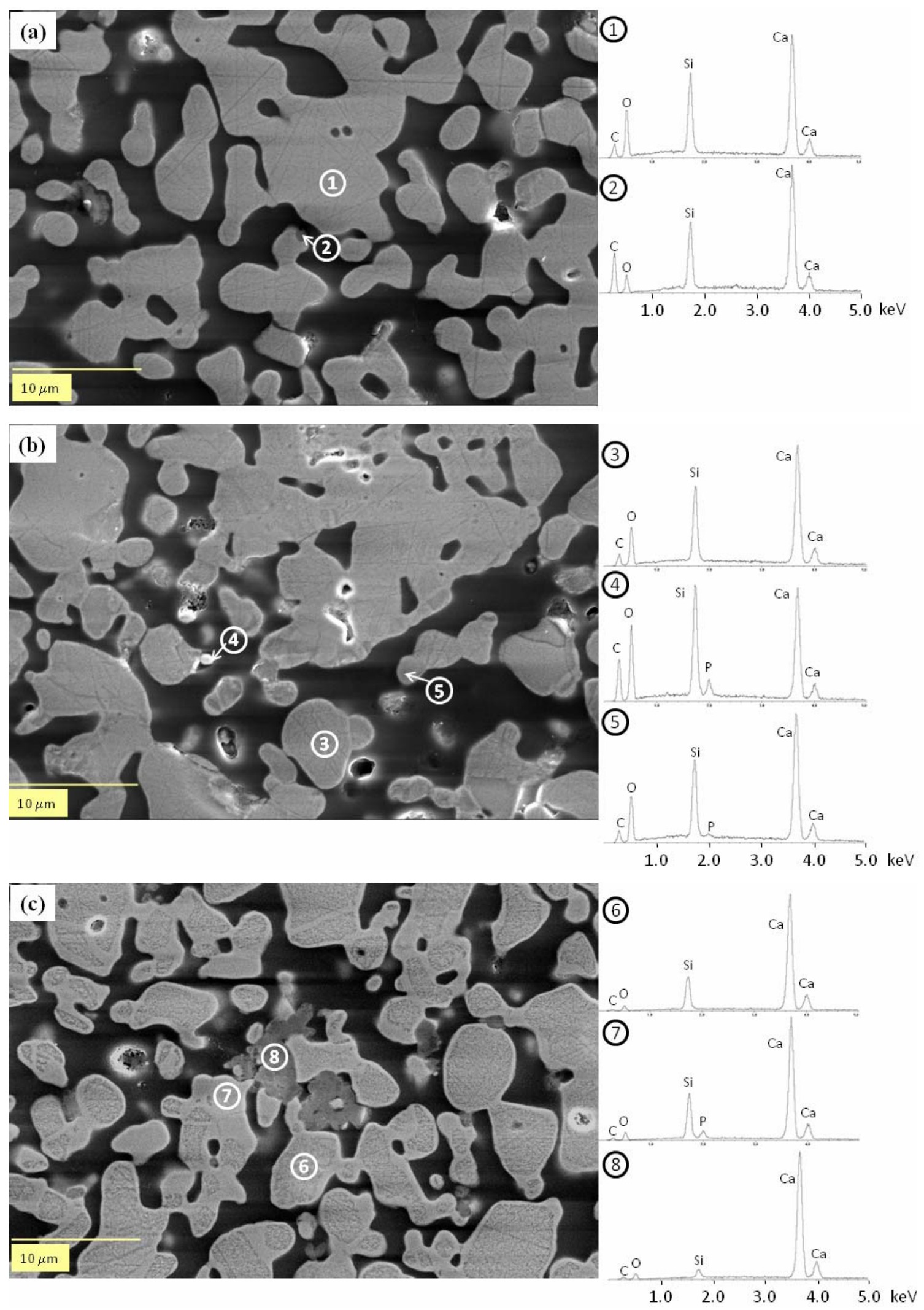

Fig. 6. Scanning electron micrographs (secondary electron images): (a) pure $\mathrm{C}_{3} \mathrm{~S}$ (b) $\mathrm{C}_{3} \mathrm{~S}$ doped with 0.1 wt. \% $\mathrm{P}_{2} \mathrm{O}_{5}$ and (c) 0.9 wt. $\% \mathrm{P}_{2} \mathrm{O}_{5}$. The regions of the EDS analyses are labelled from 1 to 8 in the SEM micrographs. 


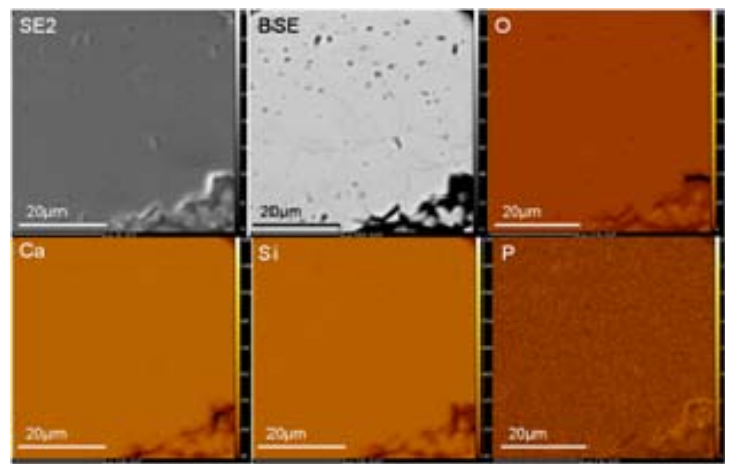

(a)

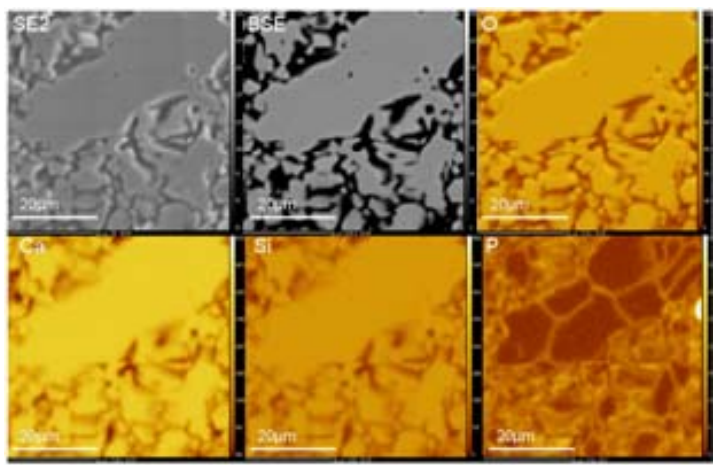

(b)

Fig. 7. EMPA X-ray maps of (a) the pure $\mathrm{C}_{3} \mathrm{~S}$ sample and (b) the doped 0.3 wt. \% $\mathrm{P}_{2} \mathrm{O}_{5}$ one: phosphorus is clearly localized at the grain boundaries of $\mathrm{C}_{3} \mathrm{~S}$ grains.

\section{Discussion}

\section{(1) $C_{3} S$ phase:}

As shown by EDS and EMPA analyses, no phosphorus is found inside the $\mathrm{C}_{3} \mathrm{~S}$ grains within the experimental resolution of the two techniques. The unit cell parameters remain quite constant. It suggests that phosphorus is not incorporated in the $\mathrm{C}_{3} \mathrm{~S}$ lattice. As the $\mathrm{P}_{2} \mathrm{O}_{5}$ content increases, the proportion of $\mathrm{C}_{3} \mathrm{~S}$ decreases and three other phases are observed. This can be attributed to a retrogradation of $\mathrm{C}_{3} \mathrm{~S}$ into $\alpha^{\prime}{ }_{\mathrm{H}}-\mathrm{C}_{2} \mathrm{~S}(\mathrm{P})$ and lime, as already described in literature.

\section{(2) $\alpha^{\prime}{ }_{H^{-}} C_{2} S(P)$ phase:}

The phase is identified for different $\mathrm{P}_{2} \mathrm{O}_{5}$ contents according to the three experiments:

- XRD: 0.5 wt. \% (Fig. 3)

- EMPA: 0.3 wt. \% (Fig. 7)

- SEM: 0.1 wt. \% (Fig. 6b)

This is due to the different detection thresholds of the three techniques. We show that $\alpha^{\prime}{ }_{\mathrm{H}}-\mathrm{C}_{2} \mathrm{~S}(\mathrm{P})$ would appear for an addition of only 0.1 wt. $\% \mathrm{P}_{2} \mathrm{O}_{5}$. Diouri et al. ${ }^{14}$ observe the retrogradation of $\mathrm{C}_{3} \mathrm{~S}$ into $\mathrm{C}_{2} \mathrm{~S}$ and $\mathrm{CaO}$ above 1.5 wt. $\%$ of $\mathrm{P}_{2} \mathrm{O}_{5}$ when $\mathrm{P}$ and $\mathrm{Mn}$ impurities are present (Table. I). These authors showed that the coupled impurities (P, Mn) stabilize the M3 large superstructure instead of the $\mathrm{T}_{1} \mathrm{C}_{3} \mathrm{~S}$ polymorph. Indeed, Mn impurity promotes the formation of the monoclinic modification $^{33}$. Our paper shows a lower solubility limit in T1 polymorph (ten times smaller), when $\mathrm{P}$ is the only impurity. 
The topographic contrast is optimized for a voltage of $8 \mathrm{kV}$. As lower acceleration voltage excites electrons only from the surface, this means that the $\alpha^{\prime}{ }_{H}-\mathrm{C}_{2} \mathrm{~S}(\mathrm{P})$ phase is located at the surface of the $\mathrm{C}_{3} \mathrm{~S}$ grains.

The detection threshold of the EDS analyses is estimated about $1 \mathrm{wt} \%$ of an element. Adding only 0.1 wt. $\% \mathrm{P}_{2} \mathrm{O}_{5}$, phosphorus is detected in $\alpha^{\prime}{ }_{\mathrm{H}}-\mathrm{C}_{2} \mathrm{~S}(\mathrm{P})$ phase, suggesting that this phase is enriched in phosphorus from the beginning. The $\alpha^{\prime}{ }_{\mathrm{H}}-\mathrm{C} 2 \mathrm{~S}(\mathrm{P})$ proportion increases and the phase covers more and more $\mathrm{C}_{3} \mathrm{~S}$ grains as the $\mathrm{P}_{2} \mathrm{O}_{5}$ content increases. At this stage of the study, it is not

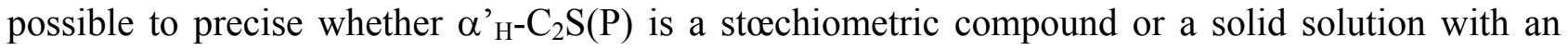
increasing substitution of $\mathrm{Si}^{4+}$ by $\mathrm{P}^{5+}$ ions. However, these results are consistent with our hydration experiments - to be published elsewhere - which clearly show an increasing of the setting time along with the phosphorus content.

One may wonder why the $\alpha^{\prime}{ }_{\mathrm{H}}-\mathrm{C}_{2} \mathrm{~S}(\mathrm{P})$ layer appears smooth. Several hypotheses can be suggested. A first hypothesis is that the layer crystallized after being melted during the synthesis of the sample $\left(1450^{\circ} \mathrm{C}\right)$. In this case, this is consistent with the broad XRD peaks observed for this phase. Another hypothesis is a possible effect of different hardness of $\mathrm{C}_{3} \mathrm{~S}$ and $\mathrm{C}_{2} \mathrm{~S}$ phases. In this case, the topological effect may be a result of the polishing of the sample for the SEM experiment, with a similar effect during the grinding process for the sample for X-ray diffraction experiments. The hardness $(\mathrm{H})$ of $\mathrm{C}_{3} \mathrm{~S}$ and $\mathrm{C}_{2} \mathrm{~S}$ phases are in the same range $(\mathrm{H} \sim 8-9 \mathrm{GPa})^{34}$, which reinforces our first hypothesis. Imaging the so-called smooth phase may be a handy tool for the $\alpha^{\prime}{ }_{\mathrm{H}}-\mathrm{C}_{2} \mathrm{~S}(\mathrm{P})$ identification.

\section{(3) Lime and portlandite:}

$\mathrm{X}$-ray diffraction shows that lime is found either as free lime $\mathrm{f}-\mathrm{CaO}$ and as portlandite $\mathrm{Ca}(\mathrm{OH})_{2}$, i.e. partially hydrated. However the free lime test usually performed on cement compounds is only able to give the overall composition without being able to distinguish between hydrated and anhydrous lime (Table III).

\section{Conclusions}

A systematic study of the effect of phosphorus addition to pure $\mathrm{C}_{3} \mathrm{~S}$ in the range 0.1 to 0.9 wt. $\% \mathrm{P}_{2} \mathrm{O}_{5}$ was performed. Our results show that adding phosphorus (alone) from 0.1 wt. $\% \mathrm{P}_{2} \mathrm{O}_{5}$ 
causes a partial decomposition of $\mathrm{C}_{3} \mathrm{~S}$ into $\alpha^{\prime}{ }_{\mathrm{H}}-\mathrm{C}_{2} \mathrm{~S}$ and $\mathrm{CaO}$ phases. This indicates (i) a low solubility limit of phosphorus in $\mathrm{T} 1 \mathrm{C}_{3} \mathrm{~S}\left(\leq 0.1\right.$ wt. $\left.\% \mathrm{P}_{2} \mathrm{O}_{5}\right)$ and (ii) supports the idea that phosphorus impurity stabilizes $\alpha^{\prime}{ }_{\mathrm{H}}-\mathrm{C}_{2} \mathrm{~S}$ polymorph. The content of phosphorus in the $\alpha^{\prime}{ }_{\mathrm{H}}-\mathrm{C}_{2} \mathrm{~S}(\mathrm{P})$ phase is more than 1 wt. $\% \mathrm{P}_{2} \mathrm{O}_{5}$. As $\mathrm{P}_{2} \mathrm{O}_{5}$ content increases, the $\alpha{ }^{\prime}{ }_{\mathrm{H}}-\mathrm{C}_{2} \mathrm{~S}(\mathrm{P})$ phase appears as layer covering more and more $\mathrm{C}_{3} \mathrm{~S}$ grains. Further quantitative microprobe analyses may be relevant in order to precise the chemical composition of $\alpha^{\prime}{ }_{\mathrm{H}}-\mathrm{C}_{2} \mathrm{~S}(\mathrm{P})$.

We propose two identification keys in order to highlight the $\alpha^{\prime}{ }_{\mathrm{H}}-\mathrm{C}_{2} \mathrm{~S}(\mathrm{P})$ phase:

- by XRD: the angular window $2 \theta_{\mathrm{Cu}}=32.8-33.2^{\circ}$ exhibits three characteristic Bragg lines that can be measured using a high resolution setup.

- by SEM: the smooth aspect of the $\alpha^{\prime}{ }_{\mathrm{H}}-\mathrm{C}_{2} \mathrm{~S}(\mathrm{P})$ superficial layer, which can be observed in topological contrast conditions at low electron energy $(8 \mathrm{keV})$.

Further experiments (at the nanometric scale) such as TEM or NMR would be necessary (i) to precise the solid limit of solubility of phosphorus in $\mathrm{C}_{3} \mathrm{~S}$ with samples doped between 0 and $0.1 \%$ and (ii) to validate the substitution of $\mathrm{Si}^{4+}$ ions by $\mathrm{P}^{5+}$ ions in $\alpha^{\prime}{ }_{\mathrm{H}^{-}} \mathrm{C}_{2} \mathrm{~S}$, as suggested by Saalfeld and Klaska: $2 \mathrm{SiO}_{4} \rightarrow 2 \mathrm{PO}_{4}+\square_{\mathrm{Va}} \mathrm{Ca}\left(\square_{\mathrm{Va}}=\right.$ vacancy).

This study is the first step towards a better characterisation of Portland cement doped with phosphorus and a better understanding of its effect on hydration kinetics and mechanical properties.

\section{Acknowledgments}

The authors are grateful to Dr. V. Pontikis (CEA Saclay, France) for his fruitful discussions and advice during this work and to M. B. Bollotte (Italcementi Group) for his cooperation and financial support. The authors also warmly thank Dr. F. Dunstetter (CEA Saclay, France) for his constructive remarks and his critical reading of the manuscript. Dr L. Pinsard-Gaudard (ICMMO, University of Paris XI) performed the acquisition of the high resolution XRD pattern. A. AllavenaValette (CECM, CNRS) and E. Leroy (LCMTR, CNRS) did their best to obtain the SEM and EMPA images. Many thanks to all of them.

\section{References}

${ }^{1}$ H. F. W. Taylor, "Cement Chemistry"; pp. 480, Edited by Thomas Telford Edition, London, 1997.

${ }^{2}$ R. W. Nurse, "The effect of phosphate on the constitution and hardening of Portland cement," J. Appl. Chem., 2 708-716 (1952). 
${ }^{3} \mathrm{H}$. Salge and P. Thormann, "Effect of phosphorus pentoxide on the constitution of Portland cement clinker," Zement Kalk Gips, 21[11] 532-539 (1973).

${ }^{4}$ W. Gutt and R. W. Nurse, "The phase composition of Portland cement clinker"; pp. 73-104 in Proceedings of the 6th International Congress on the Chemistry of Cement. Moscow, 1974.

${ }^{5}$ L. Halicz, Y. Nathan, and L. Ben-Dor, "The influence of $\mathrm{P}_{2} \mathrm{O}_{5}$ on clinker reactions," Cem. Concr. Res., 14[1] 11-18 (1984).

${ }^{6}$ W. T. Kwon, Y.-H. Kim, Y.-S. Chu, J.-K. Lee, I.-S. Kim, and S.-R. Kim, "Effect of $\mathrm{P}_{2} \mathrm{O}_{5}$ and chloride on clinkering reaction," J. Mater. Online, 1 1-8 (2005).

${ }^{7} \mathrm{~A}$. Ghose and P. Barnes, "Distribution of minor elements in cement clinkers - macroscopic and microscopic variations," World Cement Technology, 441-443 (1980).

${ }^{8}$ K. G. Kolovos, S. Tsivilis, and G. Kakali, "Study of clinker dopped with P and S compounds," $J$. Therm. Anal. Calorim., 77[3] 759-766 (2004).

${ }^{9} \mathrm{H}$. Saalfeld and K. H. Klaska, "The crystal structure of $6 \mathrm{Ca}_{2} \mathrm{SiO}_{4} \cdot \mathrm{Ca}_{3}\left(\mathrm{PO}_{4}\right)_{2}, "$ Z. Kristallogr., 155[1-2] 65-73 (1981).

${ }^{10} \mathrm{~W}$. Eysel and T. Hahn, "Polymorphism and Solid Solution of $\mathrm{Ca}_{2} \mathrm{GeO}_{4}$ and $\mathrm{Ca}_{2} \mathrm{SiO}_{4}, " \mathrm{Z}$. Kristallogr., 131 322-341 (1970).

${ }^{11}$ M. Catti, G. Gazzoni, and G. Ivaldi, "Order disorder in the $\alpha^{\prime}(\mathrm{Ca}, \mathrm{Sr})_{2} \mathrm{SiO}_{4}$ solid solution: a structural and statistical thermodynamic analysis," Acta. Cryst. B, 40 537-544 (1984).

${ }^{12}$ W. G. Mumme, R. J. Hill, G. Bushnell, and E. R. Segnit, "Rietveld crystal structure refinements, crystal chemistry and calculated powder diffraction data for the polymorphs of dicalcium silicate and related phases," N. Jb. Miner. Abh., 169[1] 35-68 (1995).

${ }^{13}$ K. Fukuda, I. Maki, S. Ito, H. Yoshida, and K. Aoki, "Structure and Microstructure Changes in Phosphorous-Bearing $\mathrm{Ca}_{2} \mathrm{SiO}_{4}$ Solid Solutions," J. Am. Ceram. Soc., 77[10] 2615-2619 (1994).

${ }^{14}$ A. Diouri, A. Boukhari, J. Aride, F. Puertas, and T. Vazquez, "Stable $\mathrm{Ca}_{3} \mathrm{SiO}_{5}$ solid solution containing manganese and phosphorus," Cem. Concr. Res., 27[8] 1203-1212 (1997).

${ }^{15}$ M. Y. Benarchid, A. Diouri, A. Boukhari, J. Aride, J. Rogez, and R. Castanet, "Elaboration and Thermal Study of Iron-Phosphorus-Substituted Dicalcium Silicate Phase," Cem. Concr. Res., 34[10] 1873-1879 (2004).

${ }^{16}$ Z. Qotaibi, A. Diouri, A. Boukhari, J. Aride, J. Rogez, and R. Castanet, "Synthesis and thermal study of chromium-phosphorus doped dicalcium silicate," World Cement Research, 30[8] 77-80 (1999).

${ }^{17} \mathrm{P}$. Arjunan and A. Kumar, "Rapid techniques for determination of free lime and free magnesia in cement clinker and portlandite in hydrates," Cem. Concr. Res., 24[2] 343-352 (1994).

${ }^{18 " E V A ~(v e r s i o n ~ 13), " ~ B r u k e r-A X S, ~ K a r l s r u h e, ~ G e r m a n y, ~ 1996-2007 . ~}$

19"TOPAS (version 3)," Bruker-AXS, Karlsruhe, Germany, 1996-2007.

${ }^{20} \mathrm{R}$. W. Cheary and A. Coelho, "A fundamental parameters approach to X-ray Line-Profile Fitting," J. Appl. Crystallogr., 25[2] 109-121 (1992).

${ }^{21}$ M. Courtial, M.-N. de Noirfontaine, F. Dunstetter, G. Gasecki, and M. Signes-Frehel, "Polymorphism of Tricalcium Silicate in Portland Cement: a fast visual identification of structure and superstructure," Powder Diffr., 18[1] 7-16 (2003).

${ }^{22} \mathrm{M}$. Regourd, "Détermination des réseaux de cristaux microscopiques. Application aux différentes formes du silicate tricalcique," Bull. Soc. Fr. Mineral. Cristallogr., 87[2] 241-272 (1964).

${ }^{23}$ Powder Diffraction File No 00-031-0301, JCPDS-ICDD.

${ }^{24}$ N. I. Golovastikov, R. G. Matveeva, and N. V. Belov, "Crystal Structure of the Tricalcium Silicate $3 \mathrm{CaO} . \mathrm{SiO}_{2}=\mathrm{C}_{3} \mathrm{~S}$," Sov. Phys. Crystallogr., 20[4] 441-445 (1975).

${ }^{25}$ Powder Diffraction File $N^{\circ}$ 01-070-1846, JCPDS-ICDD. 
${ }^{26}$ Powder Diffraction File Nº0-004-0777, JCPDS-ICDD.

${ }^{27}$ Powder Diffraction File N 00-001-1079, JCPDS-ICDD.

${ }^{28}$ Powder Diffraction File N 01-083-1494, JCPDS-ICDD.

${ }^{29}$ H. M. Rietveld, "A Profile Refinement Method for Nuclear and Magnetic Structures," J. Appl. Crystallogr., 2[2] 65-71 (1969).

30"The Rietveld Method"; pp. 298, Edited by R.A. Young, International Union of Crystallography, Oxford, 2000.

${ }^{31}$ R. W. G. Wyckoff, "Crystal Structures"; pp. 86, Vol. I, Edited by Interscience publishers, NewYork, 1965.

${ }^{32}$ H. E. Petch, "The hydrogen positions in portlandite, $\mathrm{Ca}(\mathrm{OH})_{2}$, as indicated by the electron distribution," Acta Cryst., 14[9] 950-957 (1961).

${ }^{33}$ F. Puertas, F. P. Glasser, M. T. Blanco-Varela, and T. Vaquez, "Influence of the kiln atmosphere on manganese solid solution in $\mathrm{Ca}_{3} \mathrm{SiO}_{5}$ and $\mathrm{Ca}_{2} \mathrm{SiO}_{4}$," Cem. Concr. Res., 18 783-788 (1988).

${ }^{34}$ K. Velez, S. Maximilien, D. Damidot, G. Fantozzi, and F. Sorrentino, "Determination by nanoindentation of elastic modulus and hardness of pure constituents of Portland cement clinker," Cem. Concr. Res., 31 555-561 (2001). 